\section{JURNAL ABDIMAS

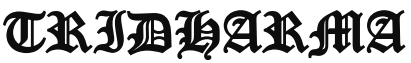 \\ AtA}

P-ISSN 2715-7105, E-ISSN 2716-070X

Jurnal ABDIMAS Vol. 2, No. 1, Januari 2021,Hal (15-24)

@Prodi Manajemen Fakultas Ekonomi Universitas Pamulang

Email: abdimasjurnal.unpam@gmail.com Telp: (021) 741-2566

\title{
PERAN KARANG TARUNA DALAM PENINGKATAN PAD \\ KELURAHAN PONDOK BENDA
}

\author{
Krisnaldy ,Ahmad Syukri,Sinta Sulistyani, Sulaiman, Sutiman \\ Dosen Ekonomi Fakultas Ekonomi Universitas Pamulang
}

Email : dosen01890@unpam.ac.id, dosen01772@unpam.ac.id, dosen01876@unpam.ac.id, dosen01673@unpam.ac.id, dosen01672@unpam.ac.id

\begin{abstract}
ABSTRAK
Pengabdian ini berjudul peran karang taruna dalam peningkatan PAD kelurahn pondok benda

Tujuan pengabdian ini adalah untuk Membantu memberikan arahan terhadap kepada karang taruna, dalam hal pengembangan PAD dan ukm dan Memberikan semangat dan motivasi bagi jajaran karang taruna dalam pengembangan kreativitas Peningkatan PAD. Metode pelaksanaan pengabdian ini dilakukan dalam beberapa kegiatan yaitu tahap survei yaitu sosialisasi dilakukan dengan menyusun berbagai hal yang akan disampaikan pada saat kegiatan pengabdian yang akan dilakukan yang meliputi: penyusunan materi yang akan diberikan, penyusunan jadwal pemberian materi, pembagian tugas tim pengabdian dan survei ke lokasi pengabdian. Tahap sosialisasi yaitu sebelum kegiatan pengabdian dilaksanakan terlebih dahulu dilakukan tahap sosialisasi yaitu melakukan silaturahmi dengan perwakilan lurah, menyampaikan maksud dan tujuan pengabdian ini. Pada tahap ini juga dilakukan jalinan kerjasama dan menentukan jadwal kegiatan pengabdian. Tim pelaksana kegiatan pengabdian pada masyarakat adalah dosen Fakultas Ekonomi jurusan manajemen sebanyak 5 orang. Tim pengabdian memberikan materi tentang penyuluhan pengembangan PAD di Pondok Benda Tangerang Selatan dan akan memberikan pelatihan disana oleh dosen UNPAM.

Kesimpulan dari pengabdian ini adalah Peserta sangat antusias terhadap pelakasanaan kegiatan ini sehingga membangkitkan keinginan untk berwirausaha. Harapan kami dengan pengabdian ini dapat membuka wawasan masyarakat yang diperoleh adalah bertambahnya keilmuan bagi para Para Masyarakat dan Ilmu yang diperoleh pada Pengabdian Masyarakat kali ini diharapkan mampu memberikan semangat baru bagi kita dalam menyampaikan materi dan motivasi serta berkontribusi bagi generasi muda, baik dilingkungan sekolah, kampus dan keluarga
\end{abstract}

\section{Kata Kunci: Karang Taruna, PAD, Efektifitas}

\begin{abstract}
ABSTRAC
This service is entitled the role of youth organizations in increasing the PAD of the pondok Benda village The purpose of this service is to help provide direction to youth organizations, in terms of developing PAD and SMEs and provide enthusiasm and motivation for youth organizations in developing creativity to increase PAD. The method of implementing this service is carried out in several activities, namely the survey stage, namely the socialization is carried out by arranging various things that will be conveyed during the service activities that will be carried out which include: preparation of the material to be given, preparation of a schedule for providing material, division of tasks for the service team and surveying the location devotion. The socialization stage, namely before the service activity is carried out, the socialization stage is carried out first, namely
\end{abstract}




\section{JURNAL ABDIMAS

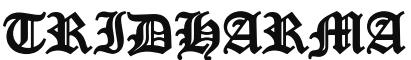

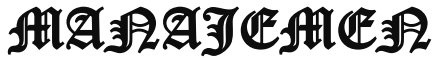

P-ISSN 2715-7105, E-ISSN 2716-070X

Jurnal ABDIMAS Vol. 2, No. 1, Januari 2021,Hal (15-24)

@ Prodi Manajemen Fakultas Ekonomi Universitas Pamulang

Email: abdimasjurnal.unpam@gmail.com Telp: (021) 741-2566

conducting a gathering with the village head representatives, conveying the aims and objectives of this service. At this stage, cooperation is also carried out and determines a schedule of service activities. The team for implementing community service activities consists of 5 lecturers at the Faculty of Economics, majoring in management. The community service team provides material on entrepreneurship development PAD in Pondok benda and will provide training there by UNPAM lecturers.

The conclusion of this service is that the participants are very enthusiastic about the implementation of this activity so that it arouses the desire for entrepreneurship. Our hope with this dedication can open up the insights of the community obtained is the increase in knowledge for the Community and the knowledge obtained at this Community Service is expected to be able to provide new enthusiasm for us in conveying material and motivation and contributing to the younger generation, both in the school environment and campus. and family

Keywords: youth organization efficiency increase in regional budgets

\section{PENDAHULUAN \\ Landasan Teori}

Berpijak pada gagasan membentuk Karang Taruna sebagai alternatif, membuat pola pembangunan dengan melalui pemberdayaan Karang Taruna. Maka pada hakekatnya Karang Taruna sudah memenuhi persyaratan untuk dapat dikembangkan sebagai Infra Struktur sosial di pedesaan/kelurahan. Sebagai infra struktur sosial, maka seharusnya posisi Karang Taruna dapat dianggap sebagai partner Pemerintah untuk mengembangkan pembangunan pedesaan. Infra struktur sosial mempunyai misi membawakan aspirasi masyarakat untuk menyuarakan pembangunan. Suara pembangunan akan semakin padu dan bulat manakala peranan pemerintah (supra struktur) dan Karang Taruna sebagai infra struktur sosial seiring seirama jalannya.

Profesionalisme Karang Taruna sangat dituntut sebagai organisasi Infra struktur sosial karena peranan dan fungsinya sebagai pelayan pembangunan dianggap sangat strategis. Kiranya tidak menutup mata bahwa masih banyak kondisi Karang Taruna yang belum memenuhi persyaratan profesional. Pada kenyataan, kualitas Karang Taruna pada saat ini sebagian besar pada klasifikasi Karang Taruna tumbuh sebagian lagi berkembang. Oleh karena itu Pemerintah Daerah di dalam fungsinya sebagai pembina teknis utama dan dinas/instansi lain sebagai pembina teknis, mempunyai kawajiban untuk meningkatkan secara terus menerus kualitas Karang Taruna. Upaya peningkatan kualitas Karang Taruna harus diimbangi oleh Karang Taruna dalam memotivasi untuk mengembangkan peranan dan fungsinya secara optimal agar tercapai desa Karang Taruna. Adapun langkah yang harus ditempuh antara lain :

1. Penataan management organisasi;

2. Menumbuhkan dan mengembangkan kader-kader profesional;

3. Penguasaan teknologi pedesaan;

4. Peningkatan dan pengembangan program kegiatan.

\section{A. Penataan Management Organisasi sebagai langkah nyata untuk menjawab tantangan persoalan organisasi. Adapun rinciannya adalah sebagai berikut :}

1. Konsolidasi Organisasi;

2. Tatanan/mekanisme organisasi yang terarah pada pengembangan Pokja-pokja;

3. Peningkatan koordinasi dan komunikasi; 


\section{JURNAL ABDIMAS

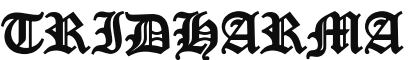

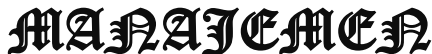

P-ISSN 2715-7105, E-ISSN 2716-070X

Jurnal ABDIMAS Vol. 2, No. 1, Januari 2021,Hal (15-24)

@ Prodi Manajemen Fakultas Ekonomi Universitas Pamulang

Email: abdimasjurnal.unpam@ gmail.com Telp: (021) 741-2566
4. Penataan administrasi yang lebih tertib.

Ruang lingkup penataan management proses organisasi Karang Taruna hendaklah berjalan searah dengan pembangunan, dimana tiap-tiap desa akan mempunyai karakter-karakter yang berbeda. Dengan demikian warna dan corak penataan management Karang Taruna akan berbeda satu sama lainnya.

\section{B. Menumbuhkan \\ Mengembangkan Kader Profesional Karang Taruna}

Karang Taruna sebagai organisasi kepemudaan yang mempunyai fungsi pelayanan. Oleh sebab itu Karang Taruna mampu berpartisipasi secara aktif di dalam proses pembangunan pedesaan. Kondisi sosial yang diharapkan Karang Taruna mampu berfungsi sebagai perencana dan sekaligus sebagai pelaksana pembangunan pedesaan. Namun demikian didalam kenyataannya memang masih di jumpai banyak kendala dan tantangan yang dihadapi Karang Taruna yang antara lain :

1. Kegiatan Karang Taruna yang masih bersifat rekreatif dan hanya sekedar pengisi waktu luang;

2. Kurangnya kader profesional;

3. Kurang tanggapnya sikap masyarakat terhadap pengembangan kualitas Karang Taruna;

4. Keraguan Pemerintah Desa terrhadap potensi Karang Taruna sehingga sedikit dibri peluang pada peran pembangunan.

Semua kendala-kendala yang disebut diatas, memang merupakan tantangan bagi eksistensi Karang Taruna. Oleh sebab itu maka pembenahan diri Karang Taruna, khususnya pada anggotanya dituntut untuk selalu meningkatkan kadar kualitas diberbagai bidang didalam menghadapi kondisi sosial/yang berkembang.

\section{Penguasaan Teknologi}

Kemampuan \& penguasaan menerapkan teknologi, yaitu teknologi sederhana yang dapat digunakan oleh setiap atau yang dapat digunakan secara secara langsung dalam proses pembangunan. Dengan demikian Karang Taruna tidak memerlukan teknologi tinggi untuk berperan aktif di dalam pembangunan. Teknologi sederhana yang harus dikuasai Karang Taruna adalah teknologi yang mampu memadukan berbagai potensi di daerah pedesaan/kelurahan, antara lain :

1. Penguasaan teknologi yang berkaitan dengan pengembangan sumber daya manusia, seperti misalnya penerapan usaha-usaha koperasi dan lain sebagainya;

2. Teknologi yang dapat mengembangkan potensi SDA seperti misalnya teknologi pengolahan lahan kering, pengolahan pasca panen dll;

3. Penguasaan teknologi terapan yang manfaatnya dirasakan secara langsung.

Dari gambaran-gambaran penguasaan teknologi yang dimaksud sebenarnya amat berkaitan dengan issue sentral yang sekarang sedang berkembang di tingkat kelurahan/pedesaan yaitu masalah perluasan lapangan kerja., masalah pengangguran, masalah urbanisasi yang tak terkendali dan masalah ketelantaran. Oleh sebab itu, maka penguasaan teknologi terapan hendaknya diukur manfaatnya untuk mangatasi dan mengantisipasi permasalahan-permasalahan diatas. Semakin tinggi tingkat kepekaan Karang Taruna terhadap persalahan yang terjadi sangat tergantung pada penguasaan teknologi tersebut diatas.

\section{Peningkatan dan Pengembangan Program Kegiatan \\ Yang dimaksud peningkatan dan} pengembangan program kegiatan, adalah program yang banyak terkait dengan program pembangunan kelurahan/pedesaan. Sementara itu kita ketahui bahwa pembangunan dari tahun ke 


\section{JURNAL ABDIMAS

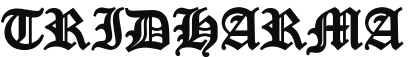

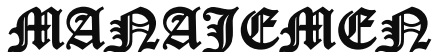

P-ISSN 2715-7105, E-ISSN 2716-070X

Jurnal ABDIMAS Vol. 2, No. 1, Januari 2021,Hal (15-24)

@Prodi Manajemen Fakultas Ekonomi Universitas Pamulang

Email: abdimasjurnal.unpam@ gmail.com Telp: (021) 741-2566 tahun semakin berfariasi dan kompleks, terutama bila dikaitkan dengan pemecahan permasalahan-permasalahan

pembangunan.

Upaya yang paling tepat yang harus dilaksanakan Karang Taruna adalah menyesuaikan program-programnya sesuai dengan bentuk dan warna program pembangunan. Gambaran yang telah ditetapkan oleh Pemerintah Desa atau Kelurahan dan LP3M, hendaknya tercermin juga pada program Karang Taruna. Oleh sebab itu diharapkan Karang Taruna aktif ke dalam proses perencanaan dan proses pelaksanaan pembangunan.

Indikasi keterlibatan Karang Taruna dalam proses pembangunan menuju Karang Taruna akan terlihat demi kegiatankegiatan Pokja-pokja yang dibentuk dan dikembangkan berdasarkan pada kepentingan-kepentingan pembangunan. Semakin luas pokja yang dikembangkan semakin menunjukan Karang Taruna berperan aktif di dalam pembangunan.

\section{TUGAS FUNGSI KARANG TARUNA}

Sesuai Pedoman Dasar Karang Taruna, pengertian Karang Taruna adalah Organisasi Sosial wadah pengembangan generasi muda yang tumbuh dan berkembang atas dasar kesadaran dan tanggung jawab sosial dari, oleh, dan untuk masyarakat terutama generasi muda di wilayah desa/kelurahan atau komunitas adat sederajat dan terutama bergerak dibidang usaha kesejahteraan sosial. Pembinaan Karang Taruna diatur dalam Permensos 83/HUK/2005 tentang Pedoman Dasar Karang Taruna. Berikut kutipan isi pedoman:

\section{Tujuan}

Tujuan Karang Taruna adalah :

1. Terwujudnya pertumbuhan dan perkembangan kesadaran dan tanggung jawab sosial setiap generasi muda warga Karang Taruna dalam mencegah, menagkal, menanggulangi dan mengantisipasi berbagai masalah sosial.

2. Terbentuknya jiwa dan semangat kejuangan generasi muda warga Karang Taruna yang Trampil dan berkepribadian serta berpengetahuan.

3. Tumbuhnya potensi dan kemampuan generasi muda dalam rangka mengembangkan keberdayaan warga Karang Taruna.

4. Termotivasinya setiap generasi muda warga Karang Taruna untuk mampu menjalin toleransi dan menjadi perekat persatuan dalam keberagaman kehidupan bermasyarakat, berbangsa dan bernegara.

5. Terjalinnya kerjasama antara generasi muda warga Karang Taruna dalam rangka mewujudkan taraf kesejahteraan sosial bagi masyarakat.

6. Terwujudnya Kesejahteraan Sosial yang semakin meningkat bagi generasi muda di desa/kelurahan atau komunitas adat sederajat yang memungkinkan pelaksanaan fungsi sosialnya sebagai manusia pembangunan yang mampu mengatasi masalah kesejahteraan sosial dilingkungannya.

7. Terwujudnya pembangunan kesejahteraan sosial generasi muda di desa/kelurahan atau komunitas adat sederajat yang dilaksanakan secara komprehensif, terpadu dan terarah serta berkesinambungan oleh Karang Taruna bersama pemerintah dan komponen masyarakat lainnya.

\section{Fungsi}

Setiap Karang Taruna melaksanakan fungsi :

1. Penyelenggara Usaha Kesejahteraan Sosial.

2. Penyelenggara Pendidikan dan Pelatihan bagi masyarakat.

3. Penyelenggara pemberdayaan masyarakat terutama generasi muda dilingkunggannya 


\section{JURNAL ABDIMAS

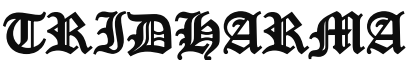

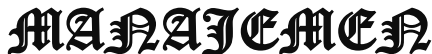

P-ISSN 2715-7105, E-ISSN 2716-070X

Jurnal ABDIMAS Vol. 2, No. 1, Januari 2021,Hal (15-24)

@Prodi Manajemen Fakultas Ekonomi Universitas Pamulang

Email: abdimasjurnal.unpam@ gmail.com Telp: (021) 741-2566 komprehensif, terpadu dan terarah serta berkesinambungan.

4. Penyelenggara

kegiatan

pengembangan jiwa kewirausahaan bagi generasi muda di lingkungannya.

5. Penanaman pengertian, memupuk dan meningkatkan kesadaran tanggung jawab sosial generasi muda.

6. Penumbuhan dan pengembangan semangat kebersamaan, jiwa kekeluargaan, kesetiakawanan sosial dan memperkuat nilai-nilai kearifan dalam bingkai Negara Kesatuan Republik Indonesia.

7. Pemupukan kreatifitas generasi muda untuk dapat mengembangkan tanggung jawab sosial yang bersifat rekreatif, kreatif, edukatif, ekonomis produktif dan kegiatan praktis lainnya dengan mendayagunakan segala sumber dan potensi kesejahteraan sosial di lingkungannya secara swadaya.

8. Penyelenggara rujukan, pendampingan, dan advokasi social bagi penyandang masalah kesejahteraan sosial.

9. Penguatan sistem jaringan komunikasi, kerjasama, informasi dan kemitraan dengan berbagai sektor lainnya.

10. Penyelenggara usaha-usaha pencegahan permasalahan sosial yang aktual.

\section{PEMBERDAYAAN KARANG TARUNA DENGAN PROGRAM LPM}

Karang Taruna merupakan wadah pembinaan generasi muda yanmg berada di Desa atau Kelurahan dalam bidang Usaha Kesejahteraan Sosial. Sebagai wadah pembinaan tentu saja mempunyai beberapa program yang akan dilaksanakan yang melibatkan seluruh komponen dan potensi yang ada di Desa atau Kelurahan yang bersangkutan. Sebagai Lembaga atau Organisasi yang bergerak di bidang Pembangunan Kesejahteraan Sosial dan berfungsi sebagai subyek. Karang Taruna sedapat mungkin mampu menunjukkan fungsi dan peranannya secara optimal.

Sebagai organisasi tentunya harus memiliki susunan pengurus dan anggota yang lengkap dan masing-masing anggota dapat melaksanakan fungsinya sesuai dengan bidang tugasnya serta dapat dapat bekerja sama dengan didukung oleh administrasi yang tertib dan teratur. Memiliki program kegiatatan yang jelas sesuai dengan kebutuhan dan permasalahan yang ada disekitarnya Program Kegiatan Karang Taruna belangsung secara melembaga terarah dan berkesinambungan serta melibatkan seluruh unsur generasi muda yang ada.

Kemampuan untuk menghimpun dana secara tetap baik yang bersumber dari Pemerintah maupun swadaya masyarakat untuk pelaksanaan program masyarakat kegiatannya Karang Taruna harus memiliki sarana prasarana yang memadai baik secara tertulis maupun administrasi Keberadaan Karang Taruna harus mampu menunjukkan peran dan fungsinya secara optimal di tengah-tengah masyarakat sehingga dapat memberikan legetimasi dan kepercayaan kepada komponen-komponen yang lain yang sama-sama berpatisipasi dalam Pembangunan Desa atau Keluraharan khususnya pembangunan dalam pembangunan dalam bidang Kesejahteraan Sosial, salah satu komponen yang berperan dalam pembangunan Desa atau Kelurahan adalah Lembaga Pemberdayaan Masyarakat ( LPM ).

LPM bersama-sama dengan komponenâ€"komponen yang lain sesuai dengan tugas, fungsi dan perananya berkepentingan membangun Desa atau Kelurahan masing-masing. Mengetahui bahwa LPM sebagai lembaga masyarakat yang mewadahi segenap aspirasi masyarakat dalam Pembangunan Desa atau Kelurahan secara menyeluruh ( Idiologi, Politik, Ekonomi, Sosial, Budaya, Agama, Pertahana dan Keamanan ) dan 


\section{JURNAL ABDIMAS

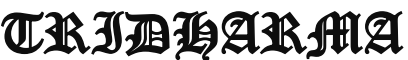

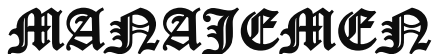

P-ISSN 2715-7105, E-ISSN 2716-070X

Jurnal ABDIMAS Vol. 2, No. 1, Januari 2021,Hal (15-24)

@ Prodi Manajemen Fakultas Ekonomi Universitas Pamulang

Email: abdimasjurnal.unpam@ gmail.com Telp: (021) 741-2566 mempunyai tugas yang menyelenggarakan musyawarah Desa atau Kelurahan maka Karang Taruna sebagai salah satu bagian dari partisipasi pembangunan bidang kesejahteraan sosial akan selalu koordinasi, konsultasi, koreksi dan memberikan kritik atau saran maupun bentuk yang lain dengan LPM.

Pemberdayaan Karang Taruna dengan program LPM dalam Usaha Kesejahteraan Sosial (UKS). Telah di ketahui bersama bahwa Karang Taruna sebagai organisasi sosial kepemudaan yang ada di Desa atau Kelurahan mempunyai tugas pokok yaitu : bersama-sama pemerintah menangani permasalahan sosial (Pembangunan dibidang Kesejahteraan Sosial). Sebagai organisasi Karang Taruna mempunyai program yang disesuaikan dengan kepentingan atau keadaan masyarakat Desa atau Kelurahan masing-masing.

Dalam program atau kegiatan yang dilaksanakan LPM dan setelah dicermati, dikaji dan dipahami maka dapat ditarik suatu garis kerjasama koordinasi, saling mengisi, saling mendukung dan saling sumbang saran dengan program atau kegiatan Karang Taruna sebagai bagian dari partisipasi masyarakat khususnya generasi muda, bidang Usaha Kesejahteraan Sosial, programprogramnya akan dilaksanakan bersamasama membahu pemerintah dalam pembangunan di Desa atau Kelurahan meskipun Karang Taruna kosentrasinya pada Pembangunan Bidang Kesejahteraan Sosial..

Sesuai dengan kondisi masing-masing Karang Tarunanya. Karang Taruna diharapkan mampu menyikapi dan menangani berbagi permasalahan kesejahteraan sosial para pemuda dan warga masyarakat umumnya, LPM sebagai wahana partisipasi masyarakat (salah satunya Karang Taruna) akan selalu memberikan spirit, dorongan dan membantu pembangunan Karang Taruna melalui program-program yang telah direncanakan Karang Taruna. Dengan bekal kemampuan dan kemapanan yang optimal, Karang Taruna akan mampu secara maksimal menangani permasalahan kesejahteraan sosial, sehingga permasalahan sosial yang ada di Desa atau Kelurahan akan menjadi berkurang atau hilang. Dengan demikian LPM mampu memberikan kontribusi kepada Karang Taruna secara optimal melalui programprogramnya dan masyarakat sendiri merasakan dampaknya yaitu permasalahan sosial berkurang, kesejahteraan sosial meningkat dan kesetiakawanan sosial maupun kebersamaan sosial menjadi kental.

Beberapa program UKS Karang Taruna yang dapat dikontribusikan dengan lembaga atau organisasi lain dan bermanfaat bagi masyarakat pada umumnya, antara lain: Pencegahan atau preventif terhadap tumbuhnya kenakalan remaja dan penyalahgunaan narkoba, minuman keras dan lain-lain melalui kegiatan olah raga, kesenian dan rekreasi dll. Pelayanan dan rehabilitasi sosial antara lain :kebersihan lingkungan, penyantunan para penyandang cacat anak terlantar secara rujukan maupun langsung, penyantunan para korban bencana dan lain-lain. Pengembangan melalui kerjasama dengan organisasi sosial yang ada, pembentukan Kelompok Usaha Bersama, ketrampilan ekonomi produktif dll. Kependudukan dan lingkungan hidup, kesehatan dan gizi, KB, pertanian dll.Program-program tersebut bersifat fleksibel (dapat berubah), mengembangkan dan tuntas tanpa menimbulkan akses-akses negatif. Adapun fungsinya antara lain : sebagai pencegahan, rehabilitasi, pengembangan dan penunjang. Selain dari program, banyak kegiatan yang dapat diprogramkan untuk membangun Desa atau Kelurahan khususnya pada bidang kesejahteraan sosial. 


\section{JURNAL ABDIMAS

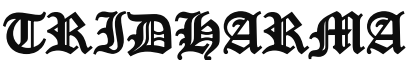

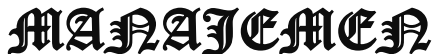

P-ISSN 2715-7105, E-ISSN 2716-070X

Jurnal ABDIMAS Vol. 2, No. 1, Januari 2021,Hal (15-24)

@Prodi Manajemen Fakultas Ekonomi Universitas Pamulang

Email: abdimasjurnal.unpam@gmail.com Telp: (021) 741-2566

\section{PERAN KARANG TARUNA DALAM PEMBERDAYAAN FAKIR MISKIN}

Pemberdayaan Fakir Miskin merupakan komitmen bersama seluruh komponen bangsa, baik pemerintah maupun masyarakat. Paradigma pemberdayaan dalam pengentasan fakir miskin merupakan pergeseran cara pandang terhadap fakir miskin sebagai obyek pembangunan selama ini. Ditengah segala keterbatasannya, kita semua menyadari bahwa Fakir Miskin adalah juga manusia yang memiliki berbagai potensi untuk dapat dikembangkan dan diberdayakan, paling tidak "agar mereka dapat menolong diri mereka sendiri", sebagaimana prinsip yang sering dikembangkan dalam pembangunan kesejahteraan sosial.

Solidaritas sosial yang tinggi, mobilitas yang tinggi, keuletan, dan orientasinya kemasa depan yang cukup kuat, merupakan diantara sekian potensi yang masih dimiliki oleh Fakir Miskin. Implementasinya tentu disesuaikan dengan kondisi daerahnya masing-masing. Karena berdasarkan wilayahnya, program pemberdayaan fakir miskin dikonsentrasikan berdasarkan karakteristik yang terbagi kedalam: wilayah hutan kemasyarakatan, wilayah pedesaan (termasuk daerah pertanian dan pegunungan), wilayah desa-kota (sub urban, termasuk kawasan industri), wilayah perkotaan, wilayah pesisir/pantai, wilayah kepulauan terpencil, wilayah perbatasan antarnegara, wilayah eks korban bencana alam, dan wilayah eks korban bencana sosial.Seiring dengan upaya-upaya pemberdayaan masyarakat dalam pembangunan kesejahteraan sosial, maka program pemberdayaan fakir miskin juga merupakan bagian yang tidak terpisahkan dari pemberdayaan potensi sumber kesejahteraan sosial yang ada dimasyarakat, diantaranya Karang Taruna. Karang Taruna adalah organisasi sosial wadah pengembangan generasi muda yang tumbuh dan berkembang atas dasar kesadaran dan tanggungjawab sosial dari, oleh, dan untuk masyarakat terutama generasi muda di desa/kelurahan atau komunitas adat sederajat yang bergerak dibidang usaha kesejahteraan sosial. Sebagai social institution yang menjadi sumberdaya sosial paling potensial di masyarakatnya, Karang Taruna diorientasikan untuk menjadi organisasi pelayanan kemanusiaan penyelenggara Usaha Kesejahteraan Sosial yang memiliki pendekatan dan standar pada pendekatan pekerjaan sosial yang memadai, karena Karang Taruna adalah juga Volunteer.

Untuk itulah, untuk menjadikan Karang Taruna sebagai organisasi atau kelompok masyarakat fungsional yang secara khusus membantu pemerintah dalam programprogram kesejahteraan sosial seperti pemberdayaan fakir miskin, maka peran Karang Taruna juga lebih diarahkan pada kegiatan-kegiatan advokasi, bimbingan, dan pendampingan terhadap implementasi program pemberdayaan fakir miskin. Hal itu juga mengingat keberadaan Karang Taruna yang tumbuh dan berkembang dihampir seluruh desa/kelurahan di Indonesia baik wilayah pedesaan, pesisir, hutan kemasyarakatan, industri, maupun eks korban bencana. Berikut ini beberapa istilah yang berhubungan dengan implementasi Karang Taruna :

1. Pemberdayaan Masyarakat adalah upaya mengembangkan potensi dan kapasitas masyarakat agar mereka dapat mengatasi ataupun menangani dengan baik permasalahan ataupun tantangan kehidupan yang sedang ataupun akan mereka alami.

2. Usaha Kesejahteraan Sosial (UKS) adalah serangkaian kegiatan yang ditujukan untuk mengatasi masalah sosial atau kerawanan sosial ekonomi dari anggota masyarakat melalui peningkatan kemampuan sumberdaya manusia dan peningkatan akses terhadap pelayanan sosial dasar dengan 


\section{JURNAL ABDIMAS

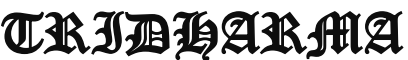

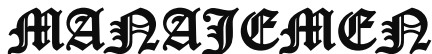

P-ISSN 2715-7105, E-ISSN 2716-070X

Jurnal ABDIMAS Vol. 2, No. 1, Januari 2021,Hal (15-24)

@Prodi Manajemen Fakultas Ekonomi Universitas Pamulang

Email: abdimasjurnal.unpam@gmail.com Telp: (021) 741-2566 mendayagunakan sumber-sumber sosial yang ada di masyarakat.

3. Fakir Miskin adalah orang yang sama sekali tidak mempunyai sumber mata pencaharian dan tidak mempunyai kemampuan memenuhi kebutuhan pokok yang layak bagi kemanusiaan atau orang yang mempunyai sumber mata pencaharian tetapi tidak dapat memenuhi kebutuhan pokok yang layak bagi kemanusiaan (PP 42/1981).

4. Usaha Ekonomis Produktif (UEP) adalah serangkaian kegiatan yang ditujukan untuk meningkatkan kemampuan dalam mengakses sumber daya ekonomi, meningkatkan kemampuan usaha ekonomi, meningkatkan produktivitas kerja, meningkatkan penghasilan dan menciptakan kemitraan usaha yang saling menguntungkan.

5. Kewirausahaan adalah suatu usaha bisnis ekonomi berdasarkan tujuan dan sistematika tertentu yang dimulai dengan skala usaha kecil dan dengan menggunakan analisis "peluang", konseptual, inovasi, dan mengarah pada pemberian contoh berdasarkan falsafah kepemimpinan.

6. Pendamping adalah seorang, sekelompok orang atau kumpulan orang dalam lembaga yang memiliki kompetensi di bidang usaha kesejahteraan sosial dan usaha ekonomis produktif melalui program peningkatan kemampuan ekonomi yang meningkatkan taraf kesejahteraan sosial masyarakat.

7. Pendampingan sosial adalah proses menjalin relasi sosial antara pendamping dengan kelompok masyarakat yang tergabung dalam program tertentu dan masyarakat sekitarnya dalam rangka memecahkan masalah, memperkuat dukungan, mendayagunakan berbagai sumber dan potensi dalam pemenuhan kebutuhan hidup, serta meningkatkan akses anggota masyarakat terhadap pelayanan sosial dasar dan fasilitas pelayanan publik lainnya.

Dengan paradigma pembangunan saat ini yang menempatkan manusia sebagai sumberdaya potensial, maka sesungguhnya pembangunan menghadapi tantangan nyata dalam bentuk upaya-upaya konstruktif kearah pemberdayaan sumberdaya potensial tersebut untuk menjadi sumberdaya yang aktual dan konkrit. Umumnya masyarakat kita di desa/kelurahan adalah sumber daya manusia yang memiliki kemampuan dan ketrampilan mengelola sumber daya alam,modal, dan teknologi, disamping sebagian lainnya juga memiliki kemampuan untuk memimpin dan mengorganisir.

Potensi ini juga tidak terkecuali ada di kalangan generasi mudanya, Karang Taruna. Peningkatan keahlian dan ketrampilan SDM di desa/kelurahan sejatinya juga dapat dikembangkan diluar jalur formal. Berbagai pelatihan bagi masyarakat di desa/kelurahan dapat dikembangkan dengan harapan mampu menghasilkan tenaga kerja dan SDM yang berkualitas. Dengan memberdayakan dan mengembangkan Karang Taruna melalui berbagai pendekatan programnya, terutama untuk menjadi pendamping bagi pemberdayaan fakir miskin, akan dapat diwujudkan masyarakat dengan sumberdaya manusia yang berkualitas dalam arti mampu menyelesaikan permasalahan yang mereka hadapi sendiri.

Sumberdaya yang sangat potensial dalam akselerasi pembangunan dengan tingkat kesejahteraan yang meningkat adalah kelembagaan sosial yang berdaya, memiliki pengetahuan dan pemahaman, berpikir kritis, dan memiliki solusi bagi setiap permasalahan masyarakatnya. Bagaimanapun dan berapapun banyaknya kekayaan alam dan jumlah penduduk yang tersedia, jika kualitas manusia dan kelembagaan sosialnya kurang, maka 


\section{JURNAL ABDIMAS

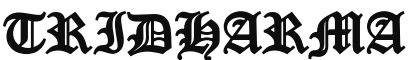

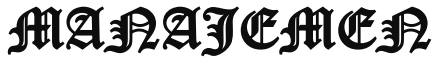

P-ISSN 2715-7105, E-ISSN 2716-070X

Jurnal ABDIMAS Vol. 2, No. 1, Januari 2021,Hal (15-24)

@ Prodi Manajemen Fakultas Ekonomi Universitas Pamulang

Email: abdimasjurnal.unpam@ gmail.com Telp: (021) 741-2566 menjadi sesuatu yang tidak bermanfaat. Sedangkan modal dan teknologi akan tergantung pada cara manusia membuat keterkaitan dan keserasiannya dengan faktor tenaga manusia itu sendiri.

Melalui bimbingan dan pendampingan dari Karang Taruna diharapkan sumberdaya manusia potensial dari kalangan fakir miskin dapat diwujudkan menjadi SDM yang aktual dan potensi ekonomi desa/kelurahan dapat menjadi sumber pendapatan asli daerah. Program Pendampingan oleh Karang Taruna dimaksudkan untuk menjembatani pemerataan tenaga sosial (Volunteer) yang bertugas mendampingi pemberdayaan fakir miskin diseluruh desa/kelurahan di Indonesia, dalam rangka ikut memecahkan masalah kemiskinan di tanah air. Sesuai dengan tujuan yang hendak dicapai adalah mendampingi dan memberdayakan kelompok-kelompok usaha masyarakat fakir miskin dalam peningkatan kesejahteraan rakyat dan pengentasan kemiskinan, sekaligus dalam kerangka menggerakkan potensi desa dalam mengatasi masalah-masalah krisis ekonomi, khususnya pangan.

\section{METODE PELAKSANAAN}

Metodepelaksanaan pengabdian ini dilakukan dalam beberapa kegiatan yaitu tahap survei yaitu sosialisasi dilakukan dengan menyusun berbagai hal yang akan disampaikan pada saat kegiatan pengabdian yang akan dilakukan yang meliputi: penyusunan materi yang akan diberikan, penyusunan jadwal pemberian materi, pembagian tugas tim pengabdian dan survei ke lokasi pengabdian. Tahap sosialisasi yaitu sebelum kegiatan pengabdian dilaksanakan terlebih dahulu dilakukan tahap sosialisasi yaitu melakukan silaturahmi dengan ketua yayasan, menyampaikan maksud dan tujuan pengabdian ini. Pada tahap ini juga dilakukan jalinan kerjasama dan menentukan jadwal kegiatan pengabdian.
Tim pelaksana kegiatan pengabdian pada masyarakat adalah dosen Fakultas Ekonomi jurusan manajemen sebanyak 5 orang. Tim pengabdian memberikan materi kepada Kelurahan Pondok Benda

\section{HASIL DAN PEMBAHASAN}

Pengabdian Masyarakat (LPPM) Universitas Pamulang yang dilakukan oleh dosen-dosen program studi Manajemen telah berjalan dengan lancar dan mendapat sambutan hangat dari tempat pelaksanaan kegiatan ini

Harapan kami dengan pengabdian ini dapat membuka wawasan masyarakat yang diperoleh adalah bertambahnya keilmuan bagi para Para Masyarakat dan Ilmu yang diperoleh pada Pengabdian Masyarakat kali ini diharapkan mampu memberikan semangat baru bagi kita dalam menyampaikan materi dan motivasi serta berkontribusi bagi generasi muda, baik dilingkungan sekolah, kampus dan keluarga.

\section{KESIMPULAN DAN SARAN}

\section{Kesimpulan}

Peserta memahami dan antusias tingi dalam mengikuti pelatihan kewirausahaan ini dan semakin yakin memulai usaha.

\section{Saran}

Setelah pengabdian ini diharapkan peserta dapat memiliki hidup yang lebih sehat secara rohani dan membangun pendapatan PAD yang lebih baik serta mengajak teman/peserta lainnya untuk ikut menjadi relawan dalam karang taruna. Tim pengabdian agar terus melakukan kegiatan-kegiatan serupa secara berkesinambungan di masa yang akan datang 


\section{JURNAL ABDIMAS

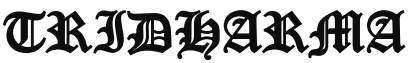

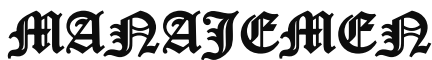

P-ISSN 2715-7105, E-ISSN 2716-070X

Jurnal ABDIMAS Vol. 2, No. 1, Januari 2021,Hal (15-24)

@Prodi Manajemen Fakultas Ekonomi Universitas Pamulang

Email: abdimasjurnal.unpam@ gmail.com Telp: (021) 741-2566

\section{DAFTAR PUSTAKA}

Arikunto, Suharsimi. 2008. DasarDasar Evaluasi Pembelajaran. Jakarta: Bumi Aksara. 308 hlmn.

Krisnaldy, 2019, Pengembangan Minat Wirausaha UMKM , Jakarta Selatan

Kartini Kartono, 2008, Pemimpin dan kepemimpinan. Jakarta: Raja Grafindo Persada

Pasaribu, V. L. D., Susanti, F., \& Hartuti, E. T. K. (2019). Memotivasi Siswa dan Siswi SMK Letris Indonesia di Dalam Menentukan Pilihan Untuk Melanjutkan Pendidikan Atau Bekerja Setelah Lulus Sekolah. Jurnal Pengabdian Dharma Laksana, 1(2), 161-172.

Pasaribu, V. L. D., Agrasadya, A., Shabrina, N., \& Krisnaldy, K. (2020). MENJADI ENTERPRENEUR MUDA YANG MEMILIKI JIWA LEADERSHIP UNTUK MENGHADAPI MASA DEPAN. Abdi Laksana, 1(1).

Pasaribu, V. L. D., Elburdah, R. P., Sudarso, E., \& Fauziah, G. (2020). PENGGUNAAN MANAJEMEN WAKTU TERHADAP PENINGKATAN PRESTASI BELAJAR DI SMP ARAISIYAH. Jurnal ABDIMAS Tri Dharma Manajemen, 1(1).

Pasaribu, V. L. D., Sulaiman, S., Sutiman, S., Thaharudin, T., \& Purnomo, B. Y. (2020). PENGENALAN LETAK POSYANDU TERDEKAT DIKELURAHAN PISANGAN DENGAN MANAJEMEN PEMASARAN REVOLUSI $\quad 4.0 \quad$ UNTUK MENINGKATKAN PENGETAHUAN MASYARAKAT LETAK DAN FUNGSI POSYANDU TERDEKAT PADA KELURAHAN PISANGAN. DEDIKASI PKM, 1(1), 105-110.
Pasaribu, V. L. D., Oktrima, B., Prabowo, B., Arianto, N., \& Haryoko, U. B. (2020). PROGAM PENDAMPINGAN DAN PENYELENGGARAAN PENDIDIKAN ANAK PADA USIA DINI TERHADAP PRESTASI BELAJAR DILINGKUNGAN RT 020 RW 009. KEL GIRI PENI. KEC WATES. YOGYAKARTA. JURNAL LOKABMAS KREATIF, 1(1), 71-75.

\section{DOKUMENTASIFOTO KEGIATAN}
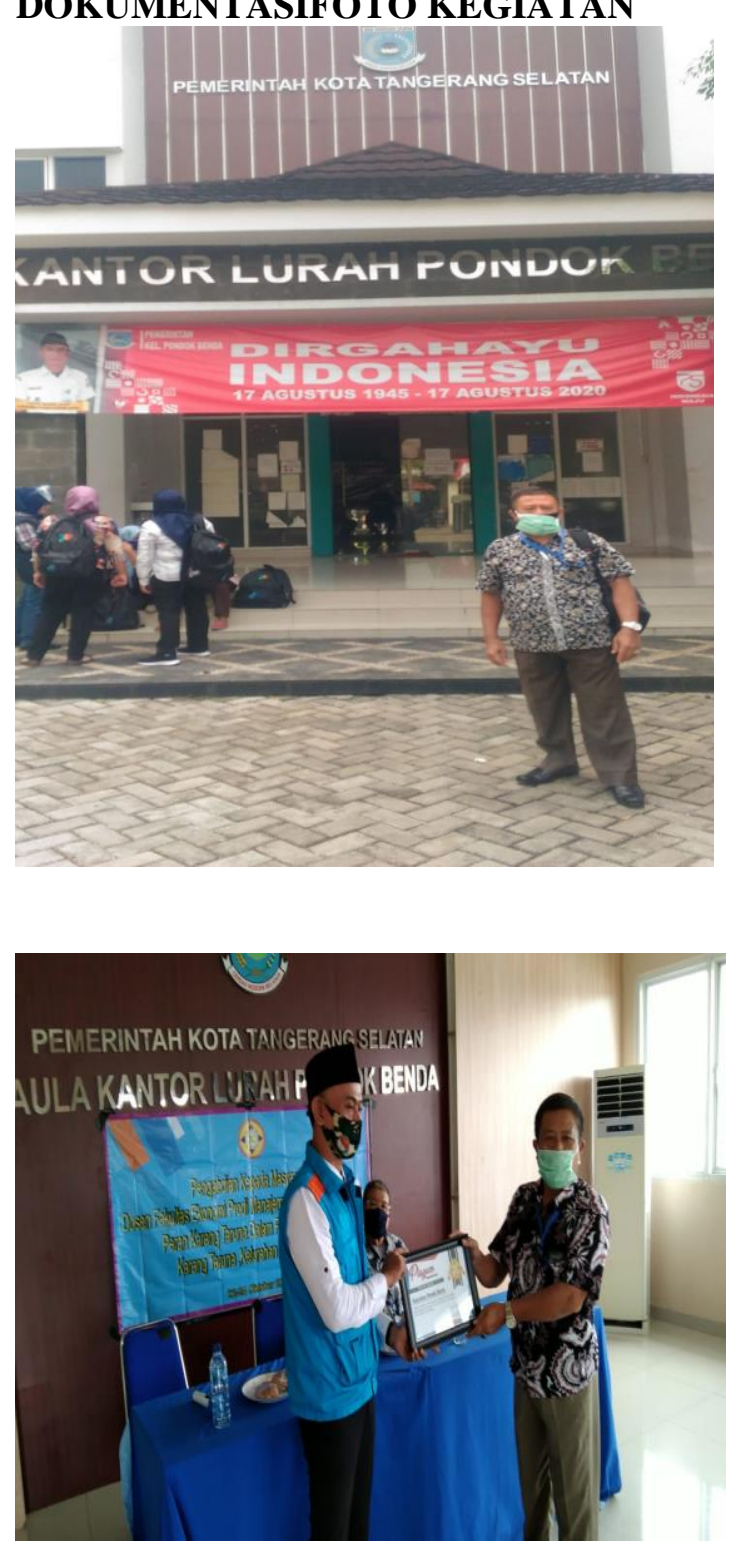
JURNAL ABDIMAS

TUIJ

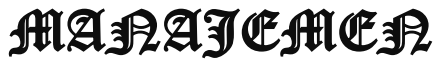

P-ISSN 2715-7105, E-ISSN 2716-070X

Jurnal ABDIMAS Vol. 2, No. 1, Januari 2021,Hal (15-24)

@ Prodi Manajemen Fakultas Ekonomi Universitas Pamulang

Email: abdimasjurnal.unpam@gmail.com Telp: (021) 741-2566 